\title{
An Analysis of Prospective Chemistry Teachers' Attitudes towards Information and Communication Technologies, and of Their Confidence in Technological and Pedagogical Content Knowledge
}

\author{
Şenol Şen* and Senar Temel \\ Faculty of Education, Hacettepe University, Ankara, Turkey
}

\begin{abstract}
This study aims to analyse prospective chemistry teachers' attitudes towards Information and Communication Technologies (ICT) as well as their confidence in Technological and Pedagogical Content Knowledge (TPACK). Information and Communication Technology Attitude Scale (ICTAS) developed by Günbatar (2014), and the Technological Pedagogical Content Knowledge Confidence Survey (TPCKCS) developed by Graham et al (2009) and adapted into Turkish by Timur and Taşar (2011) were used in this research as the tools of data collection. The study was performed in the survey model, one of the quantitative research methods. 53 prospective chemistry teachers participated in this research. The TPCKCS consists of four dimensions: technological pedagogical content knowledge, technological pedagogical knowledge, technological content knowledge, and technological knowledge. The ICTAS, on the other hand, consists of such dimensions as general tendency of ICT, access to information in virtual environments, computer hardware, use of software and communication in virtual environments. The correlations of the sub-dimensions of both scales were analysed through correlation analysis. In addition to that, a correlation analysis was performed in order to determine the relations between the total scores of both scales. At the end of the study, the correlation coefficients for the scores that prospective chemistry teachers have received from the sub-dimensions of both scales are presented.
\end{abstract}

Keywords: Attitude, Confidence, Information and Communication Technology, Technological Pedagogical Content Knowledge

\section{Introduction}

Today, when information has been increasing rapidly and technology has been gaining importance, for individuals to adjust into this process and thus to keep up to date is possible by following technological developments closely. Countries with developed technology need individuals who can use technology, can produce and can reach the increasing information. Teachers have an important role to play in educating those individuals. Thus, a need is felt for courses to raise the technology use capabilities of teachers who are going to train the next generations. Teachers' success in integrating technology with their classes is dependent on training they are going to receive. Yet,

\footnotetext{
* Hacettepe University, Faculty of Education, Beytepe-Ankara, Turkey Telephone: +90 (312) 2976787 Fax: +90 (312) 2978600 E-mail: schenolschen@ hacettepe.edu.tr
} 
technology use in classes is done only by teachers of computer education and instructional technology. However, the integration of such courses as biology, physics, and chemistry - which involve abstract concepts - with technology has become an obligation. On the other hand, the inadequacy of chemistry laboratories in schools and failure to allocate sufficient budget for chemicals hinder teachers to do experiments important for chemistry courses during their instruction. The teaching of chemistry courses with technology becomes important at this point. For instance, by means of experiments to be made possible through virtual chemistry laboratories, students can inquiry research, make observations, and thus important contributions can be made to their learning. In a similar vein, teachers who have integrated technology into their classes can also employ videos, audios, animations, and such visuals in their classes. In consequence, prospective teachers' - especially prospective chemistry teachers'attitudes towards technology as well as their confidence become important.

Prospective teachers' having positive attitudes towards technology will result in improvement in their information and communication technologies (ICT) literacy. Concepts such as "information technologies" and "information and communication technologies" emerged as a result of development in computers and computer-related technologies. Yet, through time, in consequence of using the internet along with computers, the two concepts were used together as Information and Communication Technologies (ICT) (Günbatar, 2014). ICT is any type of visual, audio, printed and written media ensuring the design, regulation of and access to information (Information Technology Association of America, 2007, as cited in Becit İşçitürk, 2012). ICT consists of hardware (equipment), software (operating system, applications, etc.), and communications facilities (local area networks, wide area and backbone networks, communication protocols, etc.) (Berce, Lanfranco, \& Vehovar, 2008). On reviewing the studies available in the literature, it was found that students had positive attitudes towards ICT- at least at medium levels- (Cavaş \& Kesercioğlu, 2003; Çelik \& Bindak, 2005; Özarslan, Çetin \& Sarıtaş, 2013), and that technology-assisted teaching raised students' achievement and supported students in terms of having positive attitudes towards courses (Arıkan, 2006; Ak1 et al., 2005; Yenice, 2003; Yiğit \& Akdeniz, 2003). Therefore, teachers should use technology in the process of teaching. Teachers' having knowledge and skills related to ICT or their acquiring such knowledge and skills will cause them to display positive attitudes towards the use of ICT (Akkoyunlu, 1986).

Along with the improvement of ICT literacy, prospective teachers will use technology in their own lives and they will also make active use of technology in their schools (Günbatar, 2014). Yet, it is not sufficient for teachers just to have positive attitudes towards using technology. It is also necessary that students develop confidence in terms of using technology in classes. Therefore, prospective teachers need to develop their technological pedagogical content knowledge before graduation from University. Technological Pedagogical Content Knowledge (TPACK) is composed of such components as content knowledge, pedagogical knowledge, technological knowledge, pedagogical content knowledge, technological pedagogical knowledge, technological content knowledge, and technological pedagogical content knowledge (Koehler \& Mishra, 2005; Koehler \& Mishra, 2009; Mishra \& Koehler, 2006). TPACK is a model which is needed in the integration of effective technology and which is based on the relations between three types of knowledge called pedagogical knowledge, technological knowledge and content knowledge as well as on the interaction between them. The design, arrangement and implementation of the teaching process to be 
performed on the basis of technology requires pedagogical and content knowledge in addition to technological knowledge and skills (Kabakçı Yurdakul, 2011). TPACK, which is based on Pedagogical content knowledge (PCK) defined by Schulman (1986), was first conceptualised by Mishra and Koehler (2006). The components of TPACK (Mishra \& Koehler 2009) are shown in Figure 1. Content knowledge (CK), Pedagogical knowledge (PK) and technological knowledge (TK) are the fundamental components constituting the model. The other components constituting the model are made up of the combination and intersection of these components. These components are pedagogical content knowledge (PCK), technological content knowledge (TCK), technological pedagogical knowledge (TPK), and technological pedagogical content knowledge (TPACK). TPACK is at the centre of the model, and it emerged with the addition of technology to the concept of PCK. Setting out from this point, TPACK was defined as the totality of knowledge that teachers should have in terms of using pedagogical and technological knowledge by relating such knowledge to content in the process of teaching a content which students are expected to learn (Koehler \& Mishra, 2005; Mishra \& Koehler, 2006).

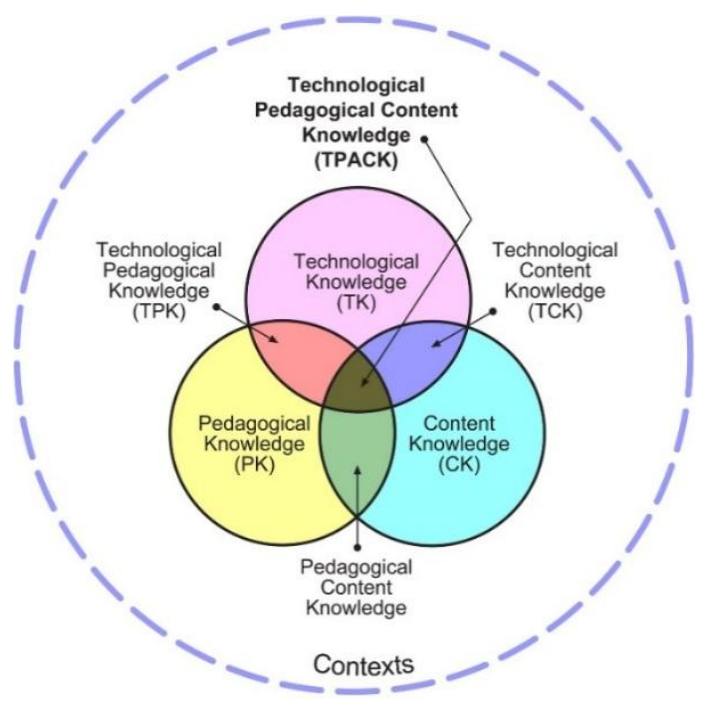

Figure 1. Technological Pedagogical Content Knowledge (TPACK) (Koehler \& Mishra, 2009)

We see that various studies related to TPACK are available in the literature. In a study performed by Niess (2005), prospective teachers' development in their TPACK in the learning-teaching process - where technological integration was done - was analysed. At the end of the study, some of the prospective teachers said that they would be able to use technology in teaching science and mathematics, and eight of them said that they needed to make more efforts in TPACK. In their research conducted by Graham et al (2009), teachers were trained, and teachers' levels of self-confidence in terms of TPACK, TPK, TCK and TK knowledge were evaluated prior to and after the training. Consequently, it was found that the increase in teachers' levels of TCK self-confidence was higher than in all the other levels. Kaya (2010) studied 41 prospective science and technology teachers' TPACK in the topics of photosynthesis and cellular respiration, and their in-class applications. At the end of the study, it was found that there was a significant correlation between prospective teachers' content knowledge and their TPACK. Moreover, it was also found that there were no significant correlations between prospective teachers' content knowledge and their TK scores. Besides, it was 
also found that prospective teachers' technological knowledge related to the content was insufficient. Taşar and Timur (2010) investigated the development in prospective science teachers' TPACK. At the end of their study, the researchers found in the light of quantitative data that prospective teachers' levels of TK self-confidence were high when TK, TCK, TPK and TPACK were considered whereas their TCK levels were low. On examining the qualitative data obtained in the research, it was found that prospective teachers' TCK levels were low.

When the literature is examined, it is seen that while prospective chemistry teachers acquire the necessary skills in terms of content knowledge and pedagogical knowledge, they do not acquire the content knowledge and pedagogical knowledge related to technology on graduation. It is not believed that computer courses included in domain teaching programmes enable prospective teachers to develop positive attitudes towards using technology or to have confidence in this respect. Teachers' inadequacy in knowledge and skills is considered to be the most important factor in their failure to integrate technology into their classes (Bingimlas, 2009; Chen, Looi, \& Chen, 2009; Gülbahar, 2008; Hew \& Brush, 2007). However, the problem does not stem only from inadequacy of knowledge in the use of technology. It also stems from inadequacy in teachers' technological pedagogical content knowledge (Hew \& Brush, 2007). Furthermore, teachers' refusal to use technology when they become teachers stems from their negative attitudes towards computers (Teo \& Noyes, 2008). Taking all these into consideration, this study aims to analyse prospective chemistry teachers' attitudes towards information and communication technologies as well as their confidence in TPACK.

\section{Method}

\section{Research Model}

This study employs an explanatory correlational research model. Correlational research is type of research in which the correlations between two or more variables are analysed without intervening those variables in a way or other. In correlational research, the changes of the variables are analysed together without trying to determine cause and effect relations. In explanatory research, however, correlations between complex variables which are thought to be related with each other are uncovered, and the levels of the correlations are determined, and efforts are made to understand important actions/situations (Fraenkel \& Wallen, 2006).

\section{Study Group}

In the study, 53 prospective chemistry teachers were included. Both scales were administered to the $2^{\text {nd }}, 3^{\text {rd }}, 4^{\text {th }}$ and $5^{\text {th }}$ year students attending a state university in the fall semester of 2014-2015 academic year.

\section{Data Collection Tools}

Information and Communication Technology Attitude Scale (ICTAS)

The scale was developed by Günbatar (2014) so as to determine undergraduate 
students' attitudes towards information and communication technologies (ICT). The factor structure of the ICT attitude scale was determined with exploratory factor analysis (EFA), and then it was confirmed through confirmatory factor analysis (CFA). The scale contained five factors and 23 items. The Cronbach's Alpha internal consistency coefficients for the sub-factors of the scale ranged between 0.899 and 0.761. The Cronbach's Alpha internal consistency coefficient for the whole scale was calculated as 0.919. The sub-dimensions included in the scale were as in the following: General Tendency of ICT, Access to Information in Virtual Environments, Computer Hardware, Use of Software and Communication in Virtual Environments.

\section{Technological Pedagogical Content Knowledge Confidence Survey (TPACKCS)}

The scale, which was developed by Graham et al. (2009) was adapted into Turkish by Timur and Taşar (2011). The findings concerning the construct validity of the scale were obtained through confirmatory factor analysis. The scale contained 31 items and four sub-dimensions. The Cronbach's Alpha internal consistency coefficient for the sub-factors of the scale ranged between 0.86 and 0.89. The Cronbach's Alpha internal consistency coefficient for the whole scale was calculated as 0.92 . The subdimensions included in the scale were as in the following: Technological Pedagogical Content Knowledge (TPACK), Technological Pedagogical Knowledge (TPK), Technological Content Knowledge (TCK) and Technological Knowledge (TK).

\section{Data Analysis}

The SPSS package programme was used in the analysis of the data obtained in the research. Correlation analysis was performed in order to determine the correlations between total scores for the scales and the scores for sub-dimensions. Because the scores for the scales did not have continuous but normal distribution, Spearman Brown's Rank Correlation Coefficient was used.

\section{Findings}

The correlations between the sub-dimensions of prospective teachers' Information and Communication Technology Attitude and Technological Pedagogical Content Knowledge Confidence, and the total scores are shown in Table 1.

Table 1. Correlations between Information and Communication Technology Attitude and Technological Pedagogical Content Knowledge Confidence

\begin{tabular}{|c|c|c|c|c|c|c|}
\hline & & TPACK & TPK & TCK & TK & $\begin{array}{c}\text { Total } \\
\text { TPCKCS } \\
\end{array}$ \\
\hline \multirow[t]{3}{*}{$\begin{array}{l}\text { General Tendency of } \\
\text { ICT }\end{array}$} & $\begin{array}{l}\text { Correlation } \\
\text { Coefficient }\end{array}$ &, $524(* *)$ &, $572(* *)$ &, 157 &, $496(* *)$ &, $532(* *)$ \\
\hline & Sig. (2-tailed) & ,000 & ,000 & ,261 & 000 & ,000 \\
\hline & $\mathrm{N}$ & 53 & 53 & 53 & 53 & 53 \\
\hline \multirow[t]{3}{*}{$\begin{array}{l}\text { Access to Information } \\
\text { in Virtual } \\
\text { Environments }\end{array}$} & $\begin{array}{l}\text { Correlation } \\
\text { Coefficient }\end{array}$ &, $481(* *)$ &, $422(* *)$ &, 178 &, $359(* *)$ & ,472(**) \\
\hline & Sig. (2-tailed) & ,000 & ,002 & ,201 & , 008 & ,000 \\
\hline & $\mathrm{N}$ & 53 & 53 & 53 & 53 & 53 \\
\hline Computer Hardware & $\begin{array}{l}\text { Correlation } \\
\text { Coefficient }\end{array}$ &, 043 & 225 &, $340(*)$ &, $359(* *)$ & ,303(*) \\
\hline
\end{tabular}




\begin{tabular}{|c|c|c|c|c|c|c|}
\hline & Sig. (2-tailed) & ,758 & 105 & 013 & ,008 & ,027 \\
\hline & $\mathrm{N}$ & 53 & 53 & 53 & 53 & 53 \\
\hline \multirow[t]{3}{*}{ Use of Software } & $\begin{array}{l}\text { Correlation } \\
\text { Coefficient }\end{array}$ &, $465(* *)$ &, $510(* *)$ & ,096 &, $734(* *)$ &, $625(* *)$ \\
\hline & Sig. (2-tailed) & ,000 & ,000 & 496 & ,000 &, 000 \\
\hline & $\mathrm{N}$ & 53 & 53 & 53 & 53 & 53 \\
\hline \multirow[t]{3}{*}{$\begin{array}{l}\text { Communication in } \\
\text { Virtual Environments }\end{array}$} & $\begin{array}{l}\text { Correlation } \\
\text { Coefficient }\end{array}$ &, $551(* *)$ &, $559(* *)$ &, 111 &, $521(* *)$ &, $595(* *)$ \\
\hline & Sig. (2-tailed) & ,000 & ,000 & ,428 & ,000 & ,000 \\
\hline & $\mathrm{N}$ & 53 & 53 & 53 & 53 & 53 \\
\hline \multirow[t]{3}{*}{ Total ICTAS } & $\begin{array}{l}\text { Correlation } \\
\text { Coefficient }\end{array}$ &, $521(* *)$ &, $596(* *)$ &, 250 &, $713(* *)$ &, $709(* *)$ \\
\hline & Sig. (2-tailed) & ,000 & ,000 & 071 & 000 & 000 \\
\hline & $\mathrm{N}$ & 53 & 53 & 53 & 53 & 53 \\
\hline
\end{tabular}

- An examination of Table 1 shows that there is a medium level positive, significant correlation between General Tendency of ICT, TPACK, TPK, and TK scores $(0,70<\mathrm{r}<0,30, \mathrm{p}<.01)$. But there are no significant correlations with TCK ( $p>.05)$. When determination coefficient $\left(r^{2}{ }_{\text {TPACK }}=0,27, r^{2}{ }_{\text {TPK }}=0,33, r^{2}{ }_{\text {TK }}=\right.$ $0,25)$ is taken into consideration, it may be said that $27 \%$ of the total variance in TPACK scores, $33 \%$ of the total variance in TPK scores, and $35 \%$ of the total variance in TK scores stem from General Tendency of ICT.

- There is a medium level positive, significant correlation between Access to Information in Virtual Environments and TPACK, TPK and TK scores $(0,70<\mathrm{r}<0,30, \mathrm{p}<.01)$. ). But there are no significant correlations with TCK $(p>.05)$. When determination coefficient $\left(r^{2}{ }_{\text {TPACK }}=0,23, r_{\mathrm{TPK}}^{2}=0,18, \mathrm{r}_{\mathrm{TK}}^{2}=0,13\right)$ is taken into consideration, it may be said that $23 \%$ of the total variance in TPACK scores, $18 \%$ of the total variance in TPK scores, and $13 \%$ of the total variance in TK scores stem from Access to Information in Virtual Environments.

- There is a medium level positive, significant correlation between Computer Hardware and TCK and TK scores $(0,70<\mathrm{r}<0,30, \mathrm{p}<.05)$. But there are no significant correlations with TPACK and TPK ( $>>05)$. When determination coefficient $\left(\mathrm{r}_{\mathrm{TCK}}^{2}=0,12, \mathrm{r}_{\mathrm{TK}}^{2}=0,13\right)$ is taken into consideration, it may be said that $12 \%$ of the total variance in TCK scores, and $13 \%$ of the total variance in TK scores stem from Computer Hardware.

- There is a medium level correlation between the scores for the Use of Software of ICT and TPACK and TPK; and a high level positive significant correlation with TK scores. $(0,70<\mathrm{r}<0,30, \mathrm{p}<.01)$. But there are no significant correlations with TCK ( $p>.05)$. When determination coefficient $\left(\mathrm{r}^{2}{ }_{\text {TPACK }}=0,27, \mathrm{r}^{2}\right.$ TPK $=0,33$, $\left.\mathrm{r}_{\mathrm{TK}}^{2}=0,25\right)$ is taken into consideration, it may be said that $27 \%$ of the total variance in TPACK scores, 33\% of the total variance in TPK scores, and $25 \%$ of the total variance in TK scores stem from the use of Software.

- There is a medium level positive, significant correlation between Communication in Virtual Environments and TPACK, TPK and TK scores $(0,70<\mathrm{r}<0,30, \mathrm{p}<.01)$. But there are no significant correlations with TCK $(p>.05)$. When determination coefficient $\left(r^{2}{ }_{\text {TPACK }}=0,22, r_{\text {TPK }}^{2}=0,26, r_{T K}^{2}=0,54\right)$ is taken into consideration, it may be said that $22 \%$ of the total variance in TPACK scores, $26 \%$ of the total variance in TPK scores, and $54 \%$ of the total variance in TK scores stem from Communication in Virtual Environments. 
- There is a high level positive, significant correlation between Total TPCKCS and Total ICTAS scores $(r=, 709, \mathrm{p}<.01)$. When determination coefficient $\left(\mathrm{r}^{2}=\right.$ 0,50 ) is taken into consideration, it may be said that $50 \%$ of the total variance in, Total TPCKCS scores stem from Total ICTAS.

\section{Conclusions and Discussion}

The data obtained from the scales were analysed through explanatory correlational research model in this research, which investigated prospective chemistry teachers' attitudes towards information and communication technologies as well as their self-confidence in technological pedagogical content knowledge. Thus, attempts were made to determine the correlations between total scores for the scales and the scales for sub-dimensions, and Spearman Brown's rank correlation coefficients were calculated. On examining the findings in general, it was seen that there were generally medium level positive and significant correlations between the sub-dimensions of both scales. On examining the correlations between total TPCKCS and total ICTAS scores, high level, positive and significant relations were observed $(\mathrm{r}=0,709, \mathrm{p}<.01)$. When determination coefficient $\left(\mathrm{r}^{2}=0,50\right)$ is taken into consideration, it may be said that $50 \%$ of the total variance in TPCKCS scores stem from total ICTAS scores. A review of literature makes it clear that studies determining students' TPACK self-confidence and self-evaluation levels (Bal \& Karademir, 2013; Graham et al., 2009;Haşlaman, Kuşkaya-Mumcu, \& Usluel, 2007; Kaya, Özdemir, Emre, \& Kaya, 2011; Sancar Tokmak, Yavuz Konokman, \& Yanpar Yelken, 2013), and studies analysing students' attitudes towards ICT (Cüre \& Özdener, 2008; Gunter, Gunter, \& Wiens, 1998; Özarslan, Çetin, \& Sarıtaş, 2013) are available in the relevant literature. Yet, it is evident that the number of studies supporting the findings we have obtained from our study in relation to the correlations between TPACK and ICT is very small. In a similar vein, Kabakçı Yurdakul (2011) studied prospective teachers' levels of efficacy in relation to technological pedagogical education and the differentiation of these levels in terms of ICT use levels, and they concluded that there were differences. Bilgin, Taşar and Ay (2012) analysed the contributions of prospective teachers' attitudes towards technology to technological pedagogical content knowledge, and they concluded that the contributions were significant. Angeli and Valanides (2005) studied prospective teachers' PCK development related to ICT. At the end of the study, it was found that prospective teachers developed in ICT-related PCK, but that they had difficulty in performing the activities in which ICT instruments were used with pedagogical methods.

\section{Recommendations}

The fact that teachers have inadequacies in application of integration beside technological inadequacies in integrating technology into their classes demonstrates the importance of ICT literacy in addition to having TPACK during prospective teachers' training. Therefore, prospective teachers should be encouraged to take part in ICTassisted learning-teaching environments. Moreover, prospective teachers could also be given opportunities to do practice related to topics in such courses as special teaching methods, teaching technologies, and material design, and thus they could gain TPACK, which would help them in integrating technology into their classes. 


\section{References}

Ak1, N. F., Gürel, Z., Muştu, C., \& Oğuz, O. (2005). Effects on students in computer usage in science education. İstanbul Ticaret Üniversitesi Fen Bilimleri Dergisi [Istanbul Commerce University Journal of Science and Technology], 4(7), 4758.

Akkoyunlu, B. (1996). Öğrencilerin bilgisayara karşı tutumları [Students’ Attitude toward computer]. Education and Science, 20(100), 15-29.

Angeli, C., \& Valanides, N. (2005). Preservice elementary teachers as information and communication technology designers: An instructional systems design model based on an expanded view of pedagogical content knowledge. Journal of Computer Assisted Learning, 21, 293-302.

Arıkan, Y. D. (2006). The effects of web-supported active learning activities on teacher trainees' attitudes towards course. Ege Eğitim Dergisi [Journal of Ege Education], 7(1), 23-41.

Bal, M.S., \& Karademir, N. (2013). Determining social science teachers' selfassessment levels with regard to their technological pedagogical content knowledge. Pamukkale University Journal of Education, 34(2), 15-32.

Becit İşçitürk, G. (2012). Examining pre-service teachers' use and acceptance of information and communication technologies in terms of several variables. (Unpublished Dissertation), Anadolu University, Eskişehir.

Berce, J., Lanfranco, S., \& Vehovar, V. (2008). e-Governance: Information and communication technology, knowledge management and learning organisation culture. Informatica, 32(2), 189-205.

Bilgin, İ., Tatar, E., \& Ay, Y. (2012). Sınıf öğretmeni adaylarının teknolojiye karşı tutumlarının teknolojik pedagojik alan bilgisine (TPAB) katkısının incelenmesi. [The examination of contribution of primary school classroom preservice teachers' attitude towards technology to technological pedagogical content knowledge (TPCAK)] 10. Ulusal Fen Bilimleri ve Matematik Eğitimi Kongresi [10 ${ }^{\text {th }}$ National Science and Mathematics Education Congress], Niğde, Turkey.

Bingimlas, K. (2009). Barriers to the successful integration of ICT in teaching and learning environments: A review of the literature. Eurasia Journal of Mathematics, Science \& Technology Education, 5(3), 235-245.

Cavaş, B., \& Kesercioğlu, T. (2003). Primary science teachers' attitudes toward computer assisted learning. Ege Journal of Education, 3(2), 35-43.

Çelik, H. C., \& Bindak, R. (2005). Examining the computer attitudes of primary school teachers according to various variables. The Inonu University Journal of the Faculty of Education, 6(10), 27-38.

Chen, F., Looi, C., \& Chen, W. (2009). Integrating technology in the classroom: A visual conceptualization of teachers' knowledge, goals and beliefs. Journal of Computer Assisted Learning, 25(5), 470-488.

Cure, F., Özdener, N. (2008). Teachers' Information and communication technologies (ICT) using achievements \& attitudes towards ICT. Hacettepe University Journal of Education, 34, 41-53.

Fraenkel, J.R., \& Wallen, N.E. (2006). How to design and evaluate research in education. New York: McGraw-Hill.

Graham, C. R., Burgoyne, N., Cantrell, P., Smith, L., St. Clair, L., \& Harris, R. (2009). TPACK Development in Science Teaching: Measuring the TPACK Confidence of In-service Science Teachers, TechTrends, Special Issue on TPACK, 53(5), 70-79. 
Gülbahar, Y. (2008). Improving the technology integration skills of prospective teachers through practice: a case study. The Turkish Online Journal of Educational Technology - TOJET, 7(4), 71-81.

Günbatar, M. S. (2014). The Study on Development of Information and Communication Technology Attitude Scale. Journal of Kırşehir Education Faculty, 15(1), 121135.

Gunter, G.A., Gunter, R.E., \& Wiens, G.A. (1998). Teaching pre-service teachers' technology: an innovative approach, Technology and Teacher Education 1998 Annual, pp. 224-227. Retrieved from: http://files.eric.ed.gov/fulltext/ED421112.pdf

Haşlaman, T., Kuşkaya-Mumcu, F., \& Usluel, Y. K. (2007). The integration of information and communication technologies in learning and teaching process: a lesson plan example. Education and Science, 32 (146), 54-63.

Hew, K. \& Brush, T. (2007). Integrating technology into K-12 teaching and learning: Current knowledge gaps and recommendations for future research. Educational Technology Research and Development, 55(3), 223-252.

Kabakçı Yurdakul, I. (2011). Examining techno pedagogical knowledge competencies of preservice teachers based on ICT usage. Hacettepe University Journal of Education, 40, 397-408.

Kaya, Z. (2010). Exploring pre-service science and technology teachers? Technological pedagogical content knowledge (TPCK) involving the topic of photosynthesis and cellular respiration. (Unpublished master's thesis), Firat University, Elazığ.

Kaya, Z., Özdemir, T. Y., Emre, İ., \& Kaya, O. N. (2011). Bilişim Teknolojileri Öğretmen Adaylarının Teknolojik Pedagojik Alan Bilgisi Özyeterlik Seviyelerinin Belirlenmesi [Determination of Preservice Information Technology Teachers' Levels of Self-Efficacy of Technological Pedagogical Content Knowledge]. 5th International Computer \& Instructional Technologies Symposium, 22-24 September 2011, Firat University, Elazığ- Turkey

Koehler, M. J., \& Mishra, P. (2005). What happens when teachers design educational technology? The development of Technological Pedagogical Content Knowledge. Journal of Educational Computing Research, 32(2), 131-152.

Koehler, M. J., \& Mishra, P. (2009). What is technological pedagogical content knowledge? Contemporary Issues in Technology and Teacher Education, 9(1). Retrieved from http://www.citejournal.org/vol9/iss1/general/article1.cfm

Mishra, P., \& Koehler, M.J. (2006). Technological pedagogical content knowledge: A framework for integrating technology in teacher knowledge. Teachers College Record, 108(6), 1017-1054.

Niess, M. L. (2005). Preparing teachers to teach science and mathematics with technology: developing a technology pedagogical content knowledge. Teaching and Teacher Education, 21(5), 509-523.

Özarslan, M., Çetin, G., \& Sarıtaş, T. (2013). Prospective biology, physics and chemistry teachers' attitudes toward information and communication technologies. Turkish Science Education, 10(2), 85-100.

Sancar Tokmak, H. Yavuz Konokman, G. \& Yanpar Yelken, T. (2013). An investigation of Mersin University early childhood pre-service teachers' selfconfidence about their technological pedagogical content knowledge (TPACK). Journal of Kırşehir Education Faculty, 14(1), 35-51.

Shulman, L. (1986). Those who understand: Knowledge growth in teaching. Educational Researcher, 15(2), 4-14. 
Tanushree, B., Jha, A. N., \& Singh, H. K. (2010). Effectiveness of ICT in e-governance with special reference to Jharkhand state. Global Journal of Computer Science and Technology, 10(14), 27-31.

Taşar, M. F., \& Timur, B. (2010). Developing technological pedagogical content knowledge in pre-service science teachers through microteaching via inquiry based interactive physics computer animations. GIREP-ICPE-MPTL Conference, 22-29 August, 2010, Reims, France.

Teo, T. \& Noyes, J. (2008). Development and validation of a computer attitude measure for young students (CAMYS). Computers in Human Behavior, 24(6), 26592667.

Timur, B., \& Taşar, M. F. (2011). The adaptation of the technological pedagogical content knowledge confidence survey into Turkish. Gaziantep University Journal of Social Sciences, 10(2), 839 -856.

Yenice, N. (2003). Bilgisayar destekli fen bilgisi öğretiminin öğrencilerin fen ve bilgisayar tutumlarına etkisi [The effect of computer based science teaching on students' attitudes of science and computer]. The Turkish Online Journal of Educational Technology - TOJET,2(4), 79-85.

Yiğit, N., \& Akdeniz, A. R. (2003). The effect of computer-assisted activities on student achievement in physics course: Electric circuits sample. Gazi University Journal of Gazi Educational Faculty (GUJGEF), 23(3), 99-113. 